\title{
Kempen Tanggungjawab Sosial Korporat dan Persepsi Khalayak: Kesan Kempen Terpilih Petronas TeRHADAP Sikap Kasih Sayang Golongan Pelajar kepada Ibu Bapa
}

\author{
Muhammad Zaiamri Zainal Abidin \\ Universiti Malaya \\ zaiamrizainal@um.edu.my \\ Nursyamira Shaid \\ Universiti Malaya \\ syamirashaid@um.edu.my \\ Hasmah Zanuddin \\ Universiti Malaya \\ hasmahz@um.edu.my
}

\section{CORPORATE SOCIAL RESPONSIBILITY (CSR) CAMPAIGN \& AUDIENCE PERCEPTIONS : THE EFFECTS OF SELECTED PETRONAS'S CSR CAMPAIGN TOWARDS STUDENT'S AFFECTIONATE ATTITUDE TO THEIR PARENTS}

\begin{abstract}
Corporate Social Responsibility (CSR) is a form of corporate commitment to society. The commitment is made to improve the economy and the quality of life of all stakeholders including employees and the community. The purpose of today's CSR does not only for the purpose of organization's branding, it is also contributed in community development especially in educating moral values. Thus, this study focuses on identifying the influence of CSR campaigns conducted by corporate organizations in an effort to create noble values among individuals. This includes research on the impact of watching the Petronas CSR advertising campaign "Burung Murai" broadcasted in 2007, especially to the youth in Malaysia. To conduct this study, set of survey questionnaire distributed to 270 students of the Faculty of Arts \& Social Sciences, University of Malaya by using random sampling. The results of the study found that there are correlations between the aspects of individual observation in influencing the formation of perception which ultimately affects the formation of pure values towards themselves.
\end{abstract}

Keywords: Corporate Social Responsibility, organization, advertising, individual viewing, formation of moral value 


\section{PENGENALAN}

Tanggungjawab Sosial Korporat (Corporate Social Responsibility-CSR) pada masa kini, bukanlah satu konsep yang asing terutamanya dalam dunia ekonomi dan perdagangan. Hal ini kerana, pelaksanaan CSR merupakan satu kaedah strategik yang menyumbang kepada kejayaan sesebuah organisasi (Franklin, Hogan, Langley, Mosdell, \& Pill, 2009). Maka dengan itu, wujud pelbagai bentuk kempen CSR yang dijalankan, ini termasuklah program berbentuk khidmat masyarakat, penganjuran aktiviti-aktiviti sukarela, pemberian sumbangan berbentuk dana daripada organisasi kepada golongan tertentu dan penyampaian mesej mengenai nilai-nilai murni melalui penerbitan kempen berbentuk iklan di televisyen (Keinert, 2008). Hal ini dilakukan adalah bertujuan untuk membina kepercayaan dan keyakinan orang awam terhadap organisasi menerusi kesedaran awam dan penyertaan pihak yang berkepentingan.

CSR menurut World Business Council merupakan satu bentuk komitmen sesebuah organisasi terhadap masyarakat (Keinert, 2008). Dengan erti kata lain, komitmen itu dilakukan bertujuan untuk meningkatkan ekonomi dan kualiti hidup semua pihak yang merangkumi para pekerja, komuniti mahupun persekitarannya. Pendapat ini juga turut disokong oleh Kotler dan Lee (2005) yang menjelaskan CSR sebagai komitmen perniagaan yang dipraktikkan dalam sesebuah organisasi dengan menyumbang sebahagian daripada sumber keuntungannya bagi meningkatkan kualiti hidup masyarakat. Dalam membicarakan konsep CSR secara mendalam, terdapat beberapa perkara penting yang perlu dijelaskan. Secara amnya, terdapat lima teras utama yang menjadi pendukung kepada perlaksanaan sesebuah kempen CSR, iaitu pembangunan sumber manusia, pengukuhan ekonomi, penyelesaian masalah sosial, pembinaan tatakerja beretika dan melindungi alam sekitar (Keinert, 2008).

Walau bagaimanapun, timbul satu persoalan yang spesifik sama ada kempen CSR yang dijalankan benar-benar memberikan kesan dalam memupuk dan membentuk nilai-nilai murni dalam kalangan masyarakat ataupun di sebaliknya. Hal ini berlaku disebabkan, pada masa ini wujud pelbagai masalah sosial terutamanya yang melibatkan golongan pelajar disiarkan dalam media massa (Utusan Malaysia, 3 Ogos 2010). Perkara ini berlaku seolaholah memberikan satu gambaran bahawa kurangnya kesedaran tentang nilai kasih sayang dalam diri golongan pelajar. Peningkatan kes berkaitan keganasan, rogol, dan pembunuhan yang melibatkan golongan pelajar telah memberi satu tamparan hebat kepada masyarakat. Maka dengan itu, timbul pelbagai persoalan dalam kalangan masyarakat adakah kempenkempen CSR yang dijalankan oleh organisasi korporat pada masa kini untuk memupuk nilai kasih sayang dalam diri generasi muda terutamanya golongan pelajar tidak memberi sebarang kesan sehinggakan berlakunya peningkatan masalah sosial.

Ekoran daripada permasalahan ini, kajian ini dilakukan bagi mengenal pasti adakah kempenCSR yang dijalankan oleh organisasi korporat memberikan kesan dalam pembentukan nilai-nilai murni dalam diri pelajar. Kajian ini berfokus pada kempen CSR yang dijalankan oleh Petronas pada tahun 2007 yang bertajuk "Burung Murai". Secara amnya, kempen CSR "Burung Murai" ini memaparkan mesej mengenai nilai kasih sayang yang wujud dalam sesebuah keluarga. Maka, melalui kajian ini, kempen tersebut dianalisis bagi mengenal pasti keberkesanannya dalam membentuk persepsi pelajar mengenai sikap kasih sayang terhadap ibu bapa. 


\section{ULASAN KAJIAN LEPAS DAN KERANGKA TEORI}

Kebanyakan kajian berbentuk ilmiah yang diterbitkan mengenai Petronas lebih tertumpu pada pengoperasian syarikat gergasi minyak tersebut, malahan hanya terdapat beberapa sahaja sumber kajian yang membicarakan mengenai kempen CSR yang dijalankan oleh Petronas. Namun begitu kajian yang dilakukan hanyalah tertumpu kepada peranan dan impak yang terhasil daripada pelaksanaan kempen CSR tersebut kepada perniagaan syarikat (Lu \& Castka, 2009, Abdul Hamid, 2009, Wan Khairuldin, 2010, \& Mohd Azmi, 2011). Maka dengan itu, bagi memperluaskan lagi skop pemahaman mengenai CSR, pengkaji juga turut membuat penyelidikan terhadap beberapa kajian lepas yang mengkaji tentang CSR. Oleh yang demikian, pada bahagian ini pengkaji akan memperbincangkan perkaitan yang wujud antara kajian-kajian berikut dengan skop kajian ini.

\section{Peranan CSR}

Menurut Jones (1980), CSR membabitkan peranan yang dimainkan oleh badan-badan korporat dalam meningkatkan lagi pembangunan masyarakat. Ini kerana peranan syarikat korporat pada masa kini bukanlah hanya terletak dalam meningkatkan penjenamaan korporat syarikat, malahan turut berperanan dalam membantu pihak kerajaan ke arah memperkasakan pembangunan masyarakat. Oleh itu, pelaksanaan sesebuah kempen CSR merupakan satu aspek yang penting dalam menyokong dasar sosial sesebuah negara melalui aktiviti-aktiviti yang dilakukan oleh badan-badan dan organisasi korporat. Kempen CSR yang dijalankan oleh sesebuah organisasi korporat bukan hanya sekadar meningkatkan penjenamaan korporat sesebuah syarikat malahan turut juga menyumbang pembangunan komuniti masyarakat.

Selain itu, melalui kajian yang dilakukan oleh Kim (2011) pula telah memperlihatkan peranan CSR dalam membentuk hubungan perniagaan kepada perniagaan (Business to Business - B to B) sesebuah organisasi dengan organisasi lain. Bagi menjayakan CSR yang dijalankan, terdapat beberapa elemen penting dalam mempengaruhi perhubungan perniagaan antara syarikat, iaitu kepuasan berasaskan kepada pencapaian perhubungan antara syarikat, perhubungan komitmen, tahap kebergantungan. Kempen CSR yang dijalankan bukan hanya sekadar berperanan dalam membina perhubungan antara publik luaran dan dalaman dengan organisasi, malahan turut juga membentuk perspektif positif kepada sesebuah organisasi dan membantu dalam membina perhubungan perniagaan antara organisasi. Walaupun, kajian ini tidak mempunyai perkaitan yang jelas dengan kajian pengkaji, melalui perbincangan ini boleh dijadikan rujukan dalam memahami kaedah dan pendekatan yang diguna dalam mengukur kesan sesuatu kempen CSR yang dijalankan.

\section{Persepsi Khalayak Terhadap CSR}

Berdasarkan kajian persepsi yang dilakukan oleh Giannarakis dan Grigoris (2001) telah memperlihatkan enam elemen utama yang mempengaruhi pembentukan konsep CSR di Greece. Antaranya ialah the sources of information for CSR (sumber informasi mengenai CSR), the classification of CSR practices (pengklasifikasian amalan CSR), the benefits and barriers from the CSR implementation (kelebihan dan halangan pelaksanaan CSR), dan the significance of stakeholders and the role of CSR in decision procedure (kepentingan pemegang saham dan peranan CSR dalam membuat keputusan). Dengan menggunakan kaedah analisis empirikal dalam kajian ini, terdapat beberapa kesimpulan mengenai pembentukan konsep CSR di Greece, iaitu 
sesebuah organisasi akan menggunakan pelbagai sumber informasi untuk menyampaikan maklumat mengenai CSR melalui media massa, manakala daripada aspek halangan utama pelaksanaan CSR pula adalah kesuntukan masa.

Berdasarkan kajian yang dilakukan oleh Diah Febrina dan Chang Peng Ke (2011) pula lebih memfokuskan perbezaan aspek pelaksanaan kempen CSR yang dikaji melalui Laman Web Korporat antara kedua-dua negara tersebut. Secara amnya, pelaksanaan kempen CSR di antara kedua-dua buah negara amatlah berbeza kerana di Malaysia menjadi satu kewajipan utama bagi sesebuah syarikat yang telah tersenarai di Bursa Malaysia untuk melaksanakan kempen CSR bagi memenuhi syarat tersebut. Di Indonesia pula, tidak terdapat satu prasyarat utama yang mewajibkan pelaksanaan kempen CSR bagi sesebuah organisasi mahupun yang sudah tersenarai dalam bursa saham. Maka dengan itu, melalui kajian ini, penulis tersebut bukan sahaja telah mengemukakan perbezaan yang wujud antara Malaysia dan Indonesia dalam aspek strategi pelaksanaan kempen CSR, malahan melalui kajian ini juga turut menyatakan perbezaan dari segi reka bentuk ilustrasi laman web dan kandungan maklumat mengenai kempen CSR. Walaupun kajian ini tidak mempunyai perkaitan secara terus dengan kajian pengkaji, tetapi melalui rujukan yang dibuat telah membantu pengkaji untuk memahami bentuk-bentuk kempen CSR yang dijalankan di Malaysia. Maka dengan maklumat yang diperolehi melalui rujukan kajian ini, pengkaji telah menggunakan beberapa maklumat penting dalam melakukan penyelidikan untuk mengetahui bentuk-bentuk kempen CSR yang dijalankan di Malaysia.

Teori Persepsi Diri diperkenalkan oleh Daryl Bem sebagai usaha untuk memberi penjelasan alternatif pada kajian-kajian percanggahan kognitif. Beliau mencadangkan, manusia sentiasa membuat kesimpulan berkaitan kepercayaannya berdasarkan kelakuannya. Hal ini kerana beliau berpendapat seseorang akan memerhati kelakuan dirinya sebagaimana dia memerhatikan kelakuan orang lain yang sama dan berdasarkan pemerhatian itu, dan dia membuat kesimpulan berkaitan kepercayaannya (Bem, 1972).

Teori ini juga mempunyai pandangan berbeza daripada teori percanggahan kognitif. Malah teori ini turut menolak berlakunya keadaan percanggahan kognitif dan dorongan daripada keadaan itu. Melalui banyak eksperimen dan contoh yang nyata, Teori Persepsi Diri turut menerangkan kelakuan sebenar yang mempengaruhi sikap dan bukan sebaliknya. Sebagai contohnya, individu yang memerhati dirinya menulis satu esei yang menentang kepercayaannya, mendapat kesimpulan iaitu pandangan berlainan juga tidak kurang baiknya dan seterusnya mengubah sikapnya (Beck, Epstein, \& Harrison, 1983).

Teori Persepsi Diri adalah salah satu daripada teori atribusi. Pengalaman dan situasi dianggap lebih penting daripada pemikiran kognitif. Hal ini disebabkan pengalaman dan situasi itu membentuk persepsi diri individu melalui interaksinya dengan pengalaman dan situasi itu. Maka, pengalaman positif sentiasa membawa kepada sikap positif individu (Beck, 1983). Maka dengan itu, pengkaji merasakan Teori Persepsi Diri mempunyai perkaitan dengan kajian ini kerana pengkaji cuba meneliti perubahan persepsi diri yang dialami oleh pelajar setelah menonton kempen CSR.

Dengan mengaplikasikan teori ini, pengkaji melihat sebenarnya nilai kasih sayang sememangnya wujud dalam diri seseorang manusia itu. Walau bagaimanapun, disebabkan oleh beberapa pengaruh negatif yang semakin menular pada diri pelajar, nilai kasih sayang terhadap ibu bapa semakin dilupai dan diabaikan dalam diri mereka. Maka dengan itu, wujudlah pelbagai bentuk masalah sosial yang berlaku pada masa kini ekoran daripada 
kurangnya kesedaran mengenai kasih sayang mereka terhadap ibu bapa. Namun begitu, sikap dan nilai pada diri seseorang itu boleh berubah apabila persepsi mereka berubah. Hal ini kerana persepsi memainkan peranan penting dalam membentuk keperibadian seseorang. Sebagai contohnya, apabila seseorang mempunyai persepsi yang positif mengenai dirinya, maka dia akan berkelakuan dan mengamalkan nilai positif 'manakala apabila seseorang itu mempunyai persepsi yang negatif pada dirinya, maka mereka lebih cenderung untuk melakukan perkara yang negatif dan mengamalkan nilai negatif dalam kehidupan sehariannya. Oleh yang demikian dapat dinyatakan disini bahawa persepsi memainkan peranan yang penting dalam membentuk keperibadian dan sikap seseorang dalam kehidupan sehariannya.

Maka dengan pernyataan tersebut pengkaji cuba mengaitkan pengaruh persepsi untuk mempengaruhi pelajar dalam memupuk sikap kasih sayang terhadap ibu bapa. Sebagaimana yang dibincangkan sebentar tadi, persepsi memainkan peranan yang penting dalam membentuk keperibadian dan sikap seseorang individu, maka sikap kasih sayang dapat dipupuk dalam diri pelajar jika persepsinya diubah ke arah itu. Bagi membentuk persepsi seseorang, pengaplikasian Teori Persepsi Diri boleh digunakan. Sebagai contohnya, melalui teori tersebut seseorang individu membentuk persepsi dirinya yang positif apabila melihat dan mengingati kembali peristiwa positif yang berlaku kepada dirinya suatu ketika dahulu. Setelah individu tersebut mengingati peristiwa tersebut dan membentuk persepsi yang positif maka sikap individu itu akan mula berubah ke arah yang lebih positif mengikut persepsi yang dibentuk dalam mindanya.

Jadi, hal ini dapat diaplikasikan dan memberi kefahaman yang jelas mengenai situasi yang akan wujud dalam kajian. Sebagai contohnya, seseorang pelajar yang menonton kempen CSR Petronas "Burung Murai" (2007) akan dipengaruhi melalui mesej yang disampaikan mengenai nilai kasih sayang anak terhadap ibubapa. Selepas itu, pelajar tersebut mula mengingati kembali situasi sama yang pernah dialami oleh mereka semasa menonton kempen CSR tersebut. Maka dengan itu, pelajar tersebut mula membentuk persepsi dirinya yang positif dan memupuk kembali nilai kasih sayang terhadap ibu bapa dalam dirinya. Oleh yang demikian, pelajar itu mula mengamalkan sikap kasih sayang terhadap ibu bapa mereka dan menjadikan nilai tersebut sebagai pegangan hidup. Kenyataan ini juga disokong seperti yang diperkatakan dalam Teori Persepsi Diri iaitu seseorang akan memerhati kelakuan dirinya sebagaimana dia memerhatikan kelakuan orang lain yang sama dan berdasarkan pemerhatian itu, dan dia membuat kesimpulan berkaitan kepercayaannya (Bem, 1972).

Secara kesimpulan, pengkaji dapat menjelaskan bahawa dengan mengaplikasikan Teori Persepsi Diri dalam kajian, sikap seseorang pelajar boleh berubah apabila persepsi mereka terhadap diri sendiri berubah. Perubahan persepsi juga boleh berlaku apabila seseorang mengubah pandangan melalui rumusan yang dibuat terhadap dirinya. Maka dengan itu, teori ini telah menjelaskan fenomena yang bakal berlaku kepada diri pelajar setelah terdedah kepada kempen CSR Petronas yang bertajuk "Burung Murai” (2007). Maka berdasarkan penelitian dan penganalisisan yang dibuat terhadap teori kajian, pengkaji telah menemukan beberapa penjelasan yang menjawab persoalan kajian. Maka dengan itu, pengkaji dapat mengemukakan beberapa hipotesis terarah atau penyataan awal bagi kajian seperti yang berikut: 
H 1: Keterdedahan individu kepada mesej media mampu membentuk dan mengubah pandangan terhadap dirinya.

H2: Persepsi seseorang dibentuk melalui pandangan atau rumusan yang dibuat dalam menilai dirinya.

H3: Persepsi berperanan dalam membentuk dan mempengaruhi sikap seseorang.

\section{KAEDAH KAJIAN}

Bagi mengendalikan kajian ini, kaedah kuantitatif menerusi proses soal selidik telah dipilih sebagai atur cara kutipan data. Sesi soal selidik ini melibatkan 270 orang responden yang terdiri daripada golongan pelajar universiti bagi tujuan mengenal pasti pengaruh pemaparan kempen CSR Petronas menerusi iklan "Burung Murai" dalam mempengaruhi pembentukan persepsi yang mana akhirnya memberi kesan terhadap pembentukan nilai-nilai murni terhadap diri mereka.

\section{Responden}

Selaras dengan pemilihan golongan pelajar universiti sebagai responden kajian, pengkaji telah memilih Fakulti Sastera dan Sains Sosial, Universiti Malaya sebagai lokasi kajian. Pemilihan responden dilakukan menerusi kaedah pensampelan rawak terhadap senarai 827 orang pelajar daripada sembilan jabatan di Fakulti Sastera dan Sains Sosial, Universiti Malaya.

Formula Krejcie dan Morgan (1970) telah digunakan bagi menentukan bilangan sampel saiz kajian ini. Saiz sampel bagi kajian ini, $S=269$ bagi saiz populasi $N=827$. Seramai 270 orang responden terlibat dengan kajian soal selidik berkenaan. Pemilihan responden kajian adalah melibatkan sampel kajian yang berumur antara 20 sehingga 31 tahun.

\section{Intrumen Kajian}

Soal selidik yang mengandungi soalan tertutup digunakan sebagai intrumen kajian. Format soal selidik adalah berasaskan skala Likert yang memperlihatkan soalan-soalan yang dibentuk dikelaskan mengikut urutan 1 hingga 5 yang mewakili daripada sangat tidak setuju kepada sangat setuju.

Soalan soal selidit terbahagi kepada empat bahagian, iaitu bahagian A berkaitan maklumat dan latar belakang responden. Pada bahagian ini, terdapat tiga soalan: umur, jenis jantina dan kaum. Bahagian kedua, iaitu Bahagian B terdiri daripada tiga soalan berkaitan aspek keterdedahan kepada mesej media. Pada bahagian ini, pengkaji menggunakan kaedah soalan berangkai yang memerlukan responden menjawab soalan prasyarat sebelum meneruskan proses soal selidik.

Seterusnya, bahagian yang ketiga, iaitu Bahagian C. mengandungi dua soalan berkaitan persepsi diri responden. Bahagian $\mathrm{D}$, atau bahagian terakhir terdiri daripada tiga soalan yang membabitkan sikap yang terhasil melalui pembentukan persepsi diri yang berlaku terhadap responden. 


\section{ANALISIS KAJIAN}

Responden kajian ini kebanyakannya terdiri daripada mereka yang berumur 20 hingga 22 tahun (55.1\%), diikuti dengan mereka yang berumur 23 hingga 25 tahun (44.4\%), dan mereka yang berumur 26 hingga 28 tahun dengan hanya $4 \%$. Seterusnya, responden perempuan telah mencatatkan peratusan tertinggi yang menyertai soal selidik dengan nilai $77 \%$ atau, manakala diikuti dengan responden lelaki yang mencatatkan peratusan dengan nilai $23 \%$. Kaum Melayu mencatatkan peratusan tertinggi yang menjawab soal selidik dengan nilai $87.2 \%$, dan kemudiannya diikuti dengan kaum Cina dan India yang mencatatkan peratusan penyertaan responden yang sama iaitu $4.9 \%$ dan lain-lain kaum pula mencatatkan peratusan dengan nilai $2.9 \%$.

\section{Pemupukan Kasih Sayang Terhadap Ibu Bapa}

Data kajian yang diperoleh menunjukkan bahawa keterdedahan individu kepada mesej media mampu membentuk dan mengubah pandangan terhadap dirinya. Hal ini dapat dilihat dari Rajah 1 bahawa daripada keseluruhan responden yang pernah menonton kempen CSR Petronas "Burung Murai", 50.6\% menyatakan mereka sangat setuju bahawa kempen tersebut memaparkan unsur kasih sayang yang wujud dalam sesebuah keluarga. Malahan, 58.8\% menyatakan mereka setuju bahawa kempen CSR Petronas "Burung Murai" telah berjaya memupuk sikap kasih sayang terhadap ibu bapa dalam diri mereka. Keadaan ini menunjukkan berlakunya proses pembentukan dan perubahan pandangan mengenai sikap kasih sayang dalam diri mereka setelah menonton kempen CSR tersebut. Maka dapat dirumuskan bahawa kerterdedahan responden kepada kempen CSR Petronas "Burung Murai" telah membentuk dan mengubah pandangan mengenai sikap kasih sayang terhadap ibu bapa dalam diri mereka. Oleh itu, H1, iaitu Keterdedahan individu kepada mesej media mampu membentuk dan mengubah pandangan terhadap dirinya, disokong melalui kajian ini.

\section{Rajah 1 : Pemupukan Kasih Sayang Terhadap Ibu Bapa}
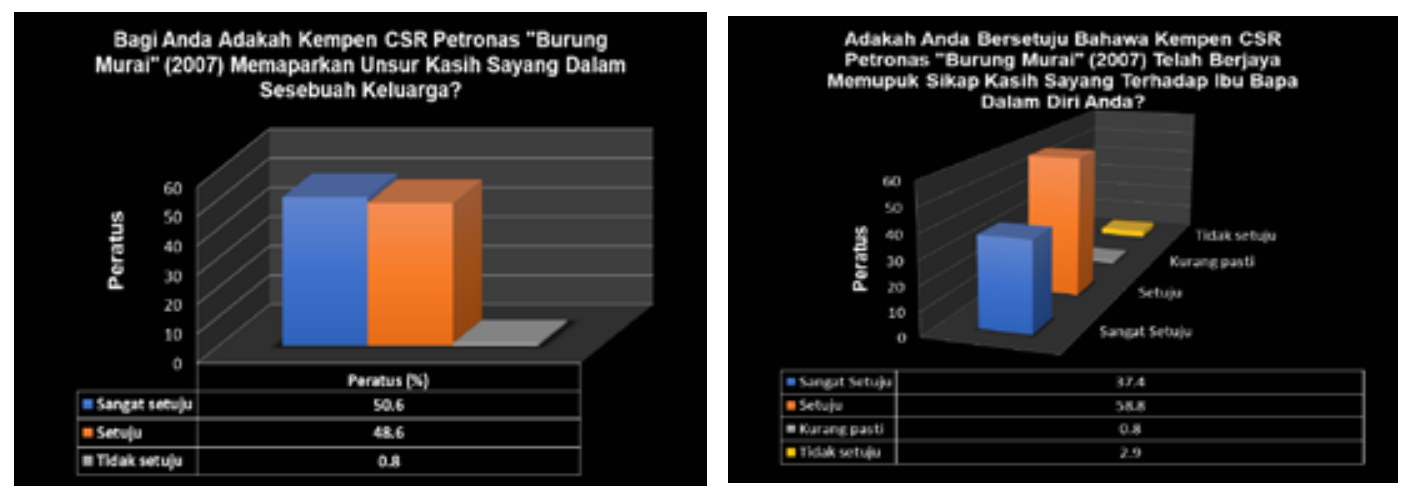

\section{Pembentukan Persepsi Khalayak}

Hasil dapatan kajian juga menunjukkan persepsi seseorang dibentuk melalui pandangan atau rumusan yang dibuat dalam menilai dirinya. Dapatan kajian (seeprti tertera dalam Rajah 2), 59.7\% responden sangat setuju bahawa sikap kasih sayang memang wujud dalam 
diri seseorang. Ini menunjukkan bahawa telah berlaku proses pembentukan pandangan mengenai sikap kasih sayang terhadap ibu bapa dalam diri responden.

Dapatan kajian yang diperoleh juga menunjukkan bahawa $52.7 \%$ daripada keseluruhan responden setuju bahawa dengan menonton kempen CSR “Burung Murai” pandangan dan rumusan mereka mulai berubah mengenai sikap kasih sayang terhadap ibu bapa memang memang wujud diri mereka. Oleh yang demikian, keadaan ini telah memperlihatkan berlakunya proses pembentukan persepsi diri yang terhasil daripada pembentukan pandangan yang berlaku pada peringkat permulaan. Dengan ini dapat disimpulkan bahawa pandangan atau rumusan yang dibuat terhadap diri responden telah mempengaruhi pembentukan persepsi diri mereka. Maka dengan itu, dapatlah dinyatakan bahawa H2, aitu Persepsi seseorang dibentuk melalui pandangan atau rumusan yang dibuat dalam menilai dirinya, disokong.

\section{Rajah 2 : Pembentukan Persepsi Khalayak}
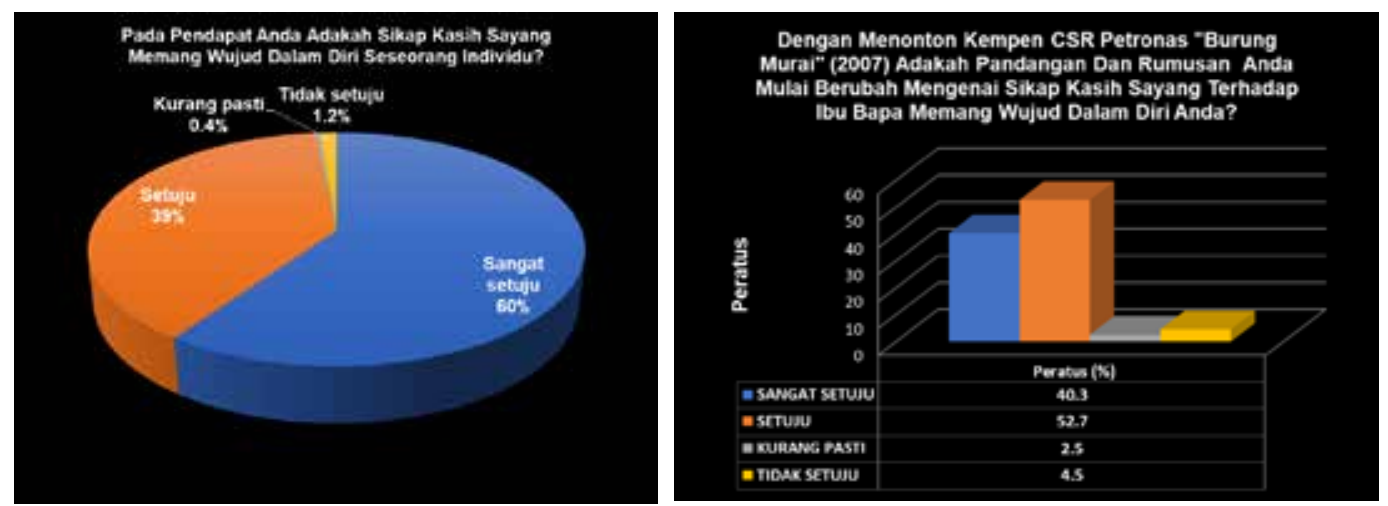

\section{Peranan Persepsi Mempengaruhi Sikap Individu}

Dapatan kajian juga memperlihatkan $64.2 \%$ responden setuju bahawa persepsi diri merupakan aspek yang penting dalam membentuk sikap seseorang individu. (Rajah 3) Maka melalui jawapan yang diberikan, pengkaji dapat mentafsir berlaku proses pembentukan persepsi diri responden pada permulaan.

Seterusnya bagi mengenal pasti pengaruh pembentukan persepsi diri yang terhasil melalui kempen CSR "Burung Murai" dapat diperjelaskan melalui bahagian kedua apabila 59.7\% kekerapan daripada responden menyatakan mereka bersetuju bahawa dengan menonton kempen CSR “Burung Murai” telah mengubah persepsi mereka bahawa wujud sikap kasih sayang terhadap ibu bapa dalam diri mereka. Keadaan ini telah menunjukkan bahawa wujudnya pengaruh yang terhasil daripada penontonan kempen tersebut terhadap proses pembentukan persepsi responden.

Bagi melihat berlakunya proses perubahan sikap pada diri responden dapat dibuktikan melalui bahagian ketiga apabila $60.5 \%$ yang mewakili responden setuju bahawa sikap mereka mulai berubah setelah menonton kempen tersebut. Maka melalui ketiga-tiga jawapan tersebut dapat diperjelaskan bahawa telah berlaku proses perubahan sikap berdasarkan persepsi diri yang berlaku pada responden setelah menonton kempen tersebut. Oleh yang demikian 
dapat dinyatakan pembentukan persepsi diri yang berlaku pada diri responden semasa menonton kempen tersebut telah membentuk dan mempengaruhi sikapnya. Dengan itu dapat disimpulkan bahawa $\mathrm{H} 3$, iaitu persepsi berperanan dalam membentuk dan mempengaruhi sikap seseorang, diterima.
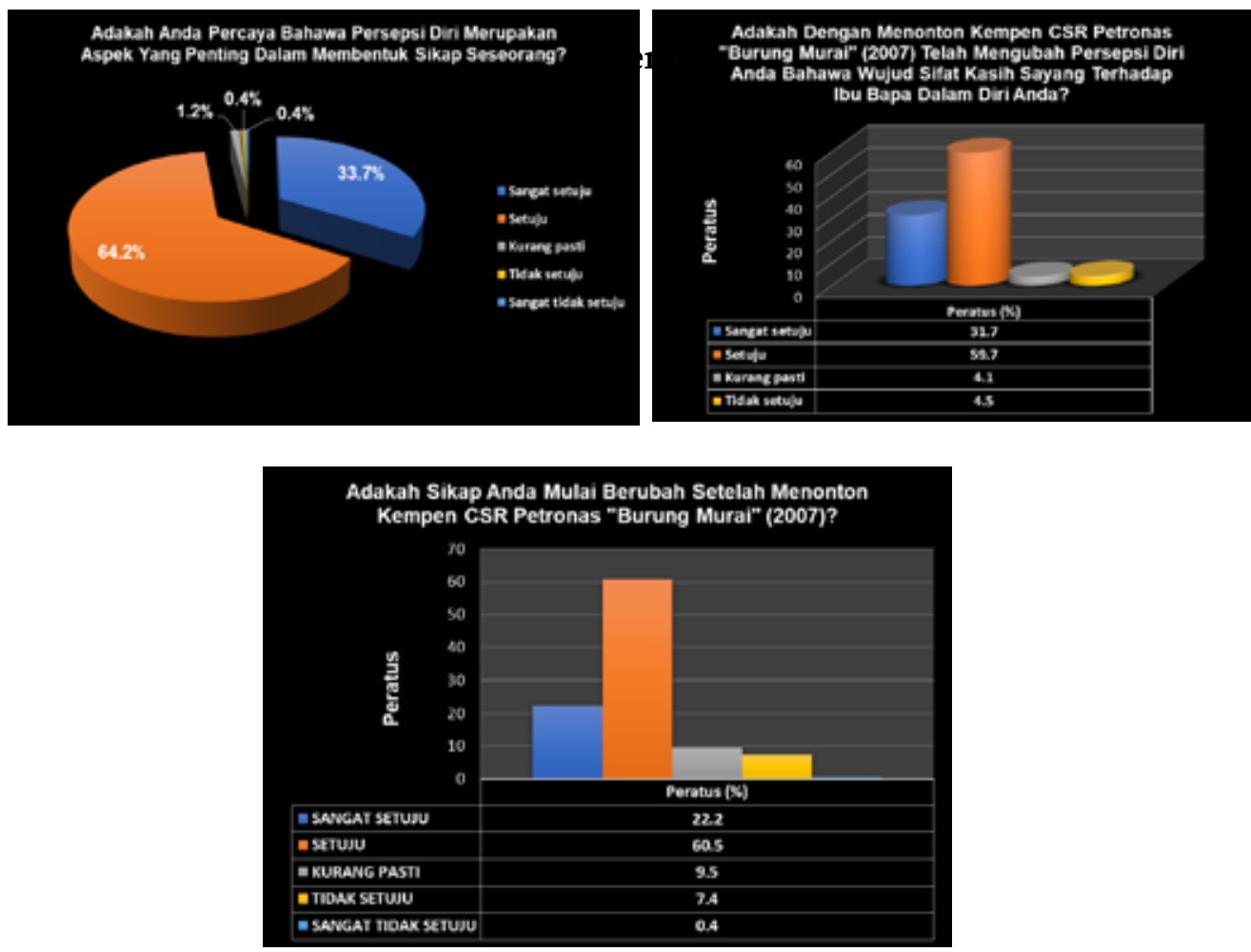

\section{PERBINCANGAN DAN KESIMPULAN}

Daripada tinjauan yang dilakukan, dapatlah dirumuskan bahawa kajian ini telah berjaya menjawab tiga hipotesis, iaitu keterdedahan individu kepada mesej media mampu membentuk dan mengubah pandangan terhadap dirinya, persepsi seseorang dibentuk melalui pandangan atau rumusan yang dibuat dalam menilai dirinya, dan persepsi berperanan dalam membentuk dan mempengaruhi sikap seseorang. Hal ini dapat dilihat melalui peratusan dan kekerapan yang diperoleh berdasarkan jawapan yang diberikan oleh responden pada setiap soalan yang terdapat pada borang soal selidik. Kebanyakan responden kerap memberikan jawapan sangat setuju dan setuju. Ini menunjukkan bahawa hipotesis yang dibina oleh pengkaji berdasarkan penyataan pada teori kajian, iaitu Teori Persepsi Diri terbukti benar.

Rata-rata responden memberikan jawapan sangat setuju dan setuju dan ini menunjukkan bahawa kebanyakan mereka yang pernah menonton kempen CSR Petronas "Burung Murai” 
sangat setuju bahawa kempen tersebut memaparkan unsur kasih sayang. Malah, mereka juga turut menyatakan setuju bahawa dengan menonton kempen tersebut telah memupuk sikap kasih sayang terhadap ibu bapa dalam diri. Maka melalui jawapan yang diberi oleh responden dapatlah dinyatakan telah berlaku proses pembentukan pandangan mengenai sikap kasih sayang setelah menonton kempen CSR tersebut.

Bahagian yang seterusnya pula merupakan bahagian $\mathrm{C}$ yang berperanan dalam menjawab hipotesis kajian yang kedua iaitu persepsi seseorang dibentuk melalui pandangan atau rumusan yang dibuat dalam menilai dirinya. Melalui hasil dapatan kajian yang diperoleh pada kedua-dua soalan tersebut dapat dinyatakan telah menjawab hipotesis kajian. Hal ini dapat dibuktikan melalui jawapan yang diberikan oleh responden yang rata-rata menyatakan sangat setuju bahawa sikap kasih sayang memang wujud dalam diri seseorang dan mereka juga turut bersetuju bahawa dengan menonton kempen CSR "Burung Murai" pandangan dan rumusan mereka mulai berubah mengenai sikap kasih sayang terhadap ibu bapa memang wujud diri mereka. Maka berdasarkan kedua-dua jawapan tersebut dapat dinyatakan telah berlaku proses pembentukan persepsi diri berdasarkan pandangan responden setelah menonton kempen itu.

Bahagian yang terakhir dalam perbincangan kajian ini ialah bahagaian D. Secara amnya, bahagian D merupakan bahagian yang menjawab hipotesis kajian yang terakhir iaitu persepsi berperanan dalam membentuk dan mempengaruhi sikap seseorang. Maka berdasarkan hasil dapatan kajian yang diperoleh kebanyakan daripada responden memberikan jawapan setuju dan sangat setuju dalam menjawab tiga soalan pada bahagian ini. Keadaan ini telah memperlihatkan responden menyokong penyataan Teori Persepsi Diri yang menyatakan persepsi diri merupakan aspek yang penting dalam mempengaruhi sikap seseorang. Hal ini dapat dilihat apabila kebanyakan daripada responden menyatakan setuju bahawa persepsi diri merupakan aspek yang penting dalam membentuk sikap seseorang individu. Malahan responden juga turut mengalami perubahan sikap setelah menonton kempen CSR Petronas "Burung Murai" dan ini dapat diperjelaskan melalui jawapan yang diberikan oleh responden yang menyatakan bersetuju bahawa dengan menonton kempen itu, telah mengubah persepsi mereka bahawa wujud sikap kasih sayang terhadap ibu bapa dalam diri dan mereka juga turut bersetuju setuju bahawa sikap mereka mulai berubah setelah menonton kempen CSR tersebut. Oleh itu berdasarkan ketiga-tiga jawapan yang diberikan oleh responden dapat dinyatakan persepsi diri memainkan peranan yang penting dalam membentuk dan mengubah sikap seseorang.

Dapat disimpulkan melalui perbincangan di atas bahawa kajian ini telah berjaya menjawab persoalan dan hipotesis kajian. Hal ini dapat dilihat melalui hasil dapatan dan perbincangan kajian yang telah memperlihatkan kempen CSR Petronas "Burung Murai" (2007) mampu membentuk persepsi dan memupuk sikap kasih sayang terhadap ibu bapa dalam diri para pelajar. Malahan melalui perbincangan kajian ini juga telah menjawab tiga hipotesis kajian yang dibentuk oleh pengkaji berdasarkan Teori Persepsi Diri.

\section{RUJUKAN}

Abdul Hamid, N. S. (2009). A study to indicate the effective areas that contribute to Petronas's Corporate Social Responsibility (CSR). (Unpublished bachelor dissertation). Universiti Teknologi MARA. Retrieved 2017, https://ir.uitm.edu.my/id/eprint/26206/1/ PPb_NUR\%20SYAZANA\%20ABDUL\%20HAMID\%20BM\%20M\%2009_5.pdf 
Ban, H. J., \& Kim, S. S. (2009). Corporate social responsibility as a source of firm's competitive advantage. Daehan Journal of Business, 22 (4), 2037-2058.

Beck, A. T., Epstein, N., \& Harrison, R. (1983). Cognitions, attitude and personality dimensions in depression. British Journal Cognitive Psychotherapy, 1 (1), 1-16.

Bem, D. J. (1972). Self-perception theory. Advances In Experiemental Social Pyschology, 6, 1-62.

Carroll, A. B. (1991). The pyramid of corporate social responsibility: Toward the moral management of organizational stakeholders. Business Horizons, 34 (4), 39-48.

Carroll, A. B. (1999). Corporate social responsibility: Evolution of a definitional construct. Business $\mathcal{E}$ society, 38 (3), 268-295.

Davis, K. (1967). Understanding the social responsibility puzzle. Business Horizons, 10 (4), 45-50.

De Schutter, O. (2008). Corporate social responsibility European style. European Law Journal, 14 (2), 203-236.

Diah, Febrina \& Kee, Chang Pee. (2011). Perbandingan bingkai-bingkai tanggungjawab sosial dalam laman web korporat Malaysia dan Indonesia. Jurnal Komunikasi, 35 (3), 21-40.

Franklin, B., Hogan, M., Langley, Q., Mosdell, N., \& Pill, E. (2009). Key Concepts in public relations. New York: Sage.

Giannarakis, G., \& Theotokas, I. (2011). The effect of financial crisis in corporate social responsibility performance. International Journal of Marketing Studies, 3 (1), 2-10.

Hamid, F. Z. A., Fadzil, F. H. H., Ismail, M. S., Ismail, S. S. S., Ali, M. N. M., Ishak, M. R. M., ,.. \& Yusof, M. Y. (2007). CSR and Legitimacy Strategy by Malaysian Companies. Corporate Social Responsibility: Our First Look, Malaysian Institute of Integrity, Kuala Lumpur, 14-35.

Hossain, M. S., \& Neogy, T. K. (2019). The current status of corporate social responsibility disclosure of Islamic Shari-based banking companies in Bangladesh. American Journal of Trade and Policy, 6 (1), 7-14.

Jones, T. M. (1980). Corporate social responsibility revisited, redifined. California Management Review, 22 (3), 59-67.

Keinert, C. (2008). Corporate social responsibility as an international strategy. Springer Science \& Business Media.

Kim, S. (2011). Transferring effects of CSR strategy on consumer responses: The synergistic model of corporate communication strategy. Journal of Public Research, 23 (2), 218-241.

Kotler, P., \& Lee, N. (2008). Corporate social responsibility: doing the most good for your company and your cause. John Wiley \& Sons.

Lu, J. Y. \& Castka, P. (2009). Corporate social responsibility in Malaysia-experts' views and perspectives. Corporate Social Responsibility and Environmental Management, 16(3), 146-154.

Marican, S. (2005). Kaedah penyelidikan sains sosial. Selangor: Pearson.

Mohd Azmi, S. (2011). Leveraging corporate social responsibility (CSR) via social networking website: knowledge exchange enhances company sustainability (Unpublished doctoral dissertation). Universiti Teknologi Petronas. Diakses daripada http://utpedia.utp.edu. my/7499/1/2011\%20-\%20Leveraging\%20corporate\%20sosial\%20responsibility\%20 \%28CSR \%29\%20Via\%20ocial\%20networking\%20website.pdf

Siron, Rusinah. (2010, Ogos 3). Remaja dan masalah sosial. Utusan Malaysia. 
Wan Khairuldin, W. N. N. (2010). The study on the effectiveness of corporate social responsibility (CSR) By Petronas in penetrating international markets (Unpublished bachelor dissertation). Universiti Teknologi MARA. Retrieved 2017, from https://ir.uitm. edu.my/id/eprint/31774/1/31774.pdf

Waddock, S. A., \& Graves, S. B. (1997). The corporate social performance-financial performance link. Strategic Management Journal, 18 (4), 303-319. 